\title{
THE HUMAN BODY FROM PHENOMENOLOGICAL AND PERSONALIST PERSPECTIVE: APPEALING TO THE DONORSHIP ISSUE
}

\author{
Vasyl Horoshko, Ulyana Lushch \\ Danylo Halytsky Lviv National Medical University Lviv, Ukraine, vasyahoros- \\ hko@gmail.com; ulyana.Iushch@gmail.com
}

Introduction. In view of the increasing medical possibilities to intervene the human body as well as the possibilities of using body parts in research and commercial enterprises, the human body is considered as a useful instrument and even a marketable commodity.

\begin{abstract}
Aim. To define the specificity of the relationship of the human being to his body and the relationship between the human beings in the world appealing to phenomenological and personalist perspective on the ethics of organ transplantation.
\end{abstract}

Materials and methods. Analysis, comparison, description, generalization, phenomenological method.

Results and discussion. The human body became an object of consumption, possession and investment. Thus, the human body is objectivated and alienated of the human Self. Jean Baudrillard distinguished four models of body: 1) animal - as a set of instincts; 2) robot - as a labour force; 3) mannequin - a body that has value and produces sexuality; 4) corpse - as the human organism examined by medicine. Hence, the human body is interpreted as an object of manipulation and ownership.

The owner of the human body is defined in three ways: 1) religious - God is the owner of human body; 2) secular - a person owns his own body; 3) socialist - society owns human body.

Personalism interprets the human person as the integrity of body and soul. To be human is also to be with others. Martin Buber distinguishes social relationship and interhuman relationship.

Martin Heidegger defines the human as Dasein - "being-there", being in the world under particular circumstances and involved in daily activities. The core of human existence is "being-inthe-world" through our body. Yet, Dasein is only possible due to Mitdasein - being and working together with others. We are "attuned" together in the world: we interact with others, feel empathy and compassion. We do not feel the other's pain but we feel it with him and we sense an urge to help him. From this perspective, organ donation is not an issue of ownership or a trade, but the "gift of life" we can offer to others or receive from them.

Conclusion. The body enables our "being-in-the-world" and "being-in-the-world-with-others". Gifts are important for establishing and maintaining moral relationships between people. Therefore, donorship should be regarded as gift-giving in the context of our attunement with the others.

Key words: organ transplantation, phenomenology, ethics, Heidegger 


\title{
ЛЮДСЬКЕ ТІЛО 3 ФЕНОМЕНОЛОГІЧНОГО ТА ПЕРСОНАЛІСТИЧНОГО ПОГЛЯДУ КРІЗЬ ПРИЗМУ ПРОБЛЕМИ ДОНОРСТВА
}

\author{
Василь Горошко, Уляна Лущ \\ Львівський національний медичний університет імені Данила Галицького \\ Львів, Україна, vasyahoroshko@gmail.com; ulyana.lushch@gmail.com
}

\begin{abstract}
Вступ. Зважаючи на зростаючі медичні можливості втручатися в організм людини, а також можливості використання частин тіла в дослідженнях та комерційних підприємствах, людське тіло вважається корисним інструментом і навіть товарним товаром.
\end{abstract}

Метою роботи стало визначення специфіку відносини людини до його тіла та відносини між людьми у світі, що звертаються до феноменологічних та персоналістичних поглядів етики трансплантації органів.

Матеріали і методи досліджень. Аналіз, порівняння, опис, узагальнення, феноменологічний метод.

Результати і обговорення. Людське тіло стало предметом споживання, володіння та інвестицій. Таким чином, людське тіло об'єктивоване і відчужене від самості. Жан Бодріяр виділив чотири моделі тіла: 1) тварина - як сукупність інстинктів; 2) робот - як робоча сила; 3) манекен - тіло, яке має цінність і виробляє сексуальність; 4) труп - як людський організм, що вивчається медициною. Отже, людське тіло інтерпретується як об'єкт маніпуляцій та власності.

Власник людського тіла визначається трьома шляхами: 1) релігійний - Бог є власником людського тіла; 2) світський - людина володіє власним тілом; 3) соціалістична - суспільство володіє людським тілом. Персоналізм тлумачить людську особу як цілісність тіла і душі. Бути людиною є також бути з іншими. Мартін Бубер відрізняє соціальні відносини та міжлюдські відносини.

Мартін Гайдеггер визначає людину як Дазайн - «існування тут», що означає бути у світі за певних обставин і брати участь у повсякденній діяльності. Отже, основа людського існування перебувати у світі через наше тіло. I все-таки, Дазайн можливий тільки завдяки Міддазайн - бути і працювати разом з іншими. Ми «гармонійні» разом у світі: ми взаємодіємо з іншими, відчуваємо співпереживання та співчуття. Ми не відчуваємо біль іншого, але ми відчуваємо це з ним і ми відчуваємо бажання допомогти йому. 3 цієї точки зору, пожертвування органів не $\epsilon$ питанням власності чи торгівлі, але «дару життя» ми можемо запропонувати іншим або отримати від них.

Висновок. Тіло дозволяє нам «бути в світі» $і$ «бути в світі-з-іншими». Подарунки важливі для встановлення та підтримки моральних відносин між людьми. Тому донорство слід розглядати як подарунок у контексті нашої взаємодії з іншими.

Ключові слова: трансплантація органів, феноменологія, етика, Гайдеггер

\section{INTRODUCTION}

In view of the increasing medical possibilities to intervene the human body as well as the possibilities of using body parts in research and commercial enterprises (e.g., organ transplantation from cadavers and living donors, usage of human corpses for medical students' practice of different procedures techniques, purchase of blood from donors, cloning human tissues in pharmaceuticals production), the human body is considered 
as a useful instrument and even a marketable commodity. The body (or its parts) became the property of individuals or firms. However, the use of "owner-property" language questions the existential integrity of the human being and brings rupture in the identity of the human body with person's Self [1-4].

Aim. To attempt defining the specificity of the relationship of the human being to his body and the relationship between the human beings in the world appealing to phenomenological and personalist perspective on the ethics of organ transplantation.

\section{MATERIAL AND METHODS}

Analysis, comparison, description, generalization, phenomenological method.

\section{RESULTS AND DISCUSSION}

The human body is omnipresent in the contemporary culture. It is essential for fashion industry and advertisement. It is exposed to hygienic and therapeutic care, diet and exercising. It underlies the cult of health and eternal youth. The human body became an object of consumption, possession and investment: it is considered as something that is supposed to give profit. Thus, the human body is objectivated and alienated of the human Self. In this respect, Jean Baudrillard distinguished four models of body: 1) animal - as flesh, as a set of instincts and desires in religion; 2) robot - as a labour force, rationally functioning machine in economics; 3 ) mannequin - a body that has value and produces sexuality; 4) corpse - as the human organism examined by medicine. Hence, the human body is interpreted as an object of manipulation and ownership [5-7].

The owner of the human body is defined in three ways: 1) religious - Ancient Greece and Christianity - God is the owner of human body, person is merely an administrator or a steward who disposes of the body for the good of others; 2) secular - John Locke, Immanuel Kant - body is the first private property of a person, but according to Kant, a person cannot dispose of it as of a mere object or means;

3) socialist - society owns human body, since the body is a consumer and a producer, has public and social side apart from individual and private. However, the use of ownership and profit terminology deprives the human being of his integrity, as it puts the body apart from the person.

On the contrary, personalism interprets the human person as the subject in corporeality, as incarnated spirit, as the integrity of body and soul. What concerns the body, therefore, affects the whole person. To be human is to be rich in unicity and originality, but, at the same time, originality is an empty concept if it does not include openness toward the other, cooperation with the others. Martin Buber distinguishes social relationship (I-it: businesslike relation, turning around owing, using and dominating) and interhuman relationship (I-Thou: personal and true, encounter, participation in the whole of coexistence).

The similar point of view is articulated by a phenomenologist Martin Heidegger. He defines the human not as distinct from the world of objects, but as Dasein - "being-there", being in the world under particular circumstances and involved in daily activities. The world is not external to our consciousness the world and the human being constitute the unity, since we give the meaning to the world by the way we are in the world, by actions and relationships we perform in the world due to our body. So the core of human existence is "being-in-the-world" through our body. Yet, Dasein is only possible due to Mitdasein - being and working together with others, since a person is never alone in her activities and situations in the world. We are "attuned" together in the world: we interact with others, feel empathy and compassion. Our body is what connects us to others. We do not feel the other's pain but we feel it with him and we sense an urge to help him [8-10].

This is the starting point for the ethics of organ transplantation: we face the suffering of the others and we can help them in some cases. From personalist and phenomenological perspective, organ donation is not the result of contract negotiation, not an issue of ownership, not a trade, but the "gift of life" we can offer to others or receive from them, as Thomas H. Murray summarizes.

\section{CONCLUSION}

The human body is not a property, not a resource, not a commodity. The body enables our "being-in-the-world" and "being-in-theworld-with-others": through the body we per- 
form our activities in the world and interact with other people. Through attunement with the others we give meaning to our actions and fulfill ourselves. One becomes human through encountering the other-that-oneself. Gifts are important for establishing and maintaining moral relationships between people within so- ciety and for respecting human values as they underscore our interdependence and the value of solidarity and human dignity. Therefore, donorship should be regarded as gift-giving in the context of our attunement with the others.

\section{REFERENCES}

1. Scheper-Hughes, N. 2003. Rotten trade: Millennial capitalism, human values and global justice in organs trafficking. Journal of Human Rights 2:197-226.

2. Svenaeus $F$. The phenomenology of health and illness. InHandbook of phenomenology and medicine 2001:87-108. Springer, Dordrecht.

3. Weimar W, MA. Bos, JJ. Busschbach (eds.). Organ transplantation: Ethical, legal and psychosocial aspects. Towards a common European policy. Lengerich: Pabst. 2008.

4. Engelhardt HT. The foundations of bioethics. Oxford University Press; 1996.

5. Richards JR. Commentary. An ethical market in human organs. Journal of medical ethics. 2003 Jun $1 ; 29(3): 139-40$.

6. Heidegger M. Die frage nach der technik. Vorträge und aufsätze. 1954;1:13-44.

7. Heidegger M. Grundbegriffe der aristotelischen Philosophie (Gesamtausgabe 18). Frankfurt am Main. 2002.

8. Leder D. Whose body? What body? The metaphysics of organ transplantation. InPersons and their bodies: Rights, responsibilities, relationships 1999:233-264. Springer Netherlands.

9. Svenaeus F. Phenomenology of medicine. In The Blackwell companion to phenomenology and existentialism, ed. H.L. Dreyfus and M.A. Wrathall. 2006:412-424. London: Blackwell.

10. Zaner RM. The context of self: A phenomenological inquiry using medicine as a clue. Athens: Ohio University Press. 1981.

Стаття надійшла 27.10.17

Після допрацювання 17.11.17

Підписана до друку 20.12.17 